Original scientific paper

UDK:327(4):323(497)

DOI:10.5937/jrs14-22898

Received: 20 December 2017 / Accepted:15 August 2019

\title{
The EU Approach to Security Provision in the Western Balkans and the Horn of Africa*
}

\author{
ANNEMARIE PEEN RODT et $a l .{ }^{* *}$ \\ Royal Danish Defence College, Denmark
}

\begin{abstract}
This article appraises the EU's approach to preventing further in security in the Western Balkans and the Horn of Africa. The purpose of this endeavour is to determine whether EU efforts meet needs on the ground as well as in Brussels. The article identifies similar sources albeit different degrees of instability across the two regions. It reviews EU strategies and CSDP missions deployed in response and evaluates the effectiveness of two such missions: EULEX Kosovo and EUCAP Nestor/Somalia. The study does not find failures as such in the strategies developed or missions deployed, but it does conclude that while relatively effective from an EU perspective this approach is less effective in providing security on the ground.
\end{abstract}

Keywords: European Union (EU), Western Balkans, Horn of Africa, EULEX Kosovo, EUCAP Nestor/Somalia, Common Security and Defence Policy (CSDP), regional strategy, security provision, prevention and capacity building.

* This project received funding from the European Union's Horizon 2020 research and innovation programme under grant agreement No 653227 for the EU-CIVCAP Project: Preventing and Responding to Conflict - Developing EU CIVilian CAPabilities for a Sustainable Peace. The part of that research project, which this article disseminates the results of, is described in further detail in Rodt et al. 2017. Report on EU Conflict Prevention and Peacebuilding in the Horn of Africa and Western Balkans (EU-CIVCAP Deliverable 5.1). The authors are grateful to the EU-CIVCAP leadership and the editorial and peer reviewers of this article. The views presented are entirely the authors' own.

*** Other authors who contributed to this article: JOHANNES TVILLING (Royal Danish Defence College, Denmark), PETER HORNE ZAARTSDAHL (Roskilde University, Denmark), NABILA HABBIDA (European Peacebuilding Liaison Office, Belgium), ERIN GILLETTE (Transparency Solutions, Somalia), SAVANNAH SIMONS (Transparency Solutions, Somalia), KHADIR ABDI (Transparency Solutions, Somalia), JENNY BERGLUND (European Union Satellite Center, Spain), VIRGINIA FERNANDEZ ARGUEDAS (European Union Satellite Center, Spain), SONJA STOJANOVIĆ GAJIĆ (Belgrade Center for Security Policy, Serbia), MARIJA IGNJATIJEVIĆ (Belgrade Center for Security Policy, Serbia). Corresponding author: anro@fak.dk.. 


\section{Introduction}

The European Union (EU) has long pursued peace through prevention. Regional cooperation and capacity building are believed to have brought peace to Europe and has therefore been promoted beyond its borders. Over the past 15 years, the EU has supported this security strategy through the deployment of Common Security and Defence Policy (CSDP) missions. ${ }^{1}$ But does it work? This enquiry focuses on the EU's practical support for security provision on the ground through CSDP missions. Specifically, it appraises the implementation of European security strategy in the Western Balkans and the Horn of Africa, two regions that the Union itself has singled out as priority areas in which to prevent further instability.

The article is structured into five sections. The first introduces the research design. The second analyses two regional security complexes in which the EU has engaged. The third reviews EU strategies and CSDP missions deployed in these regions, examining the Union's activities so far as well as its ambitions for the future. The fourth section selects and studies two specific initiatives: the European Union Rule of Law Mission (EULEX) in Kosovo and the Regional European Union Maritime Security Capacity Building Mission (EUCAP) in the Horn of Africa and Western Indian Ocean, later renamed EUCAP Somalia. The fifth section discusses whether the EU has effectively built local capacity that prevents further insecurity in these two countries and regions. Finally, the article synthesises five key lessons for the future.

\section{Research Design}

The empirical focus of this research is on the Western Balkans and the Horn of Africa. This reflects the EU's priority to prevent further insecurity on its borders to the East and South. ${ }^{2}$ The study begins by conducting a comparative analysis of these two regional security complexes. The level of analysis is regional with a focus on challenges and priorities for security provision shared across both areas. This is not to undermine differences between or indeed within these regions, but rather to explore whether and if so what can be done at and across the regional level- and whether the EU is effective in this regard. This is important as the EU assumes regional strategies towards security provision in both areas.

To explore the effectiveness of this approach on the ground, the analysis moves from the regional level to the national and then local level. To this end, the study compares specific CSDP missions from each region. In the development of capabilities for security provision, two missions - EULEX Kosovo and EUCAP Nestor/Somalia - are particularly relevant, as these are key CSDP deployments in each region. The two are similar in their typology as civilian CSDP missions, but differ in their mandates as well as the contexts

1 Council of the European Union 2003.

2 Ibid. 
within which they have deployed. The analytical approach applied is a comparative case study. It explores operational effectiveness by integrating perspectives from the intervener and those intervened upon. It goes on to consider what was achieved - or not - as well as the way in which this was sought achieved. The two missions are thus appraised using a two-pronged approach to evaluating effectiveness, reviewing first internal perspectives from within the EU and then external perspectives on the ground, appraising both goals attained and the appropriateness of means applied. Building on existing methodology for evaluating effectiveness in CSDP missions ${ }^{3}$, the comparative case study is structured and focused around four research questions. First, did the mission achieve the EU's strategic goals and operational objectives? Second, was the mandate implemented in a timely, efficient and cost-effective manner? Third, has the mission contributed to preventing further insecurity? Fourth and finally, did the mission apply proportional measures of prevention?

Data collection and analysis was informed by a state-of-the-art literature review to ensure that this research builds upon and makes a genuine contribution to existing knowledge and practice. Desk studies of official strategies, documents and reports were undertaken. Primary data was collected through fieldwork in the Horn of Africa and the Western Balkans. Fifteen semi-structured interviews were conducted with current and former staff from EU agencies, missions and member states as well as with representatives from governmental and non-governmental organisations representing various views on the ground. Additionally, the Horn of Africa study was informed by interviews facilitated by the Somalia-based partners to this project conducted in collaboration with other scholars. The work of external researchers is referenced accordingly.

\section{Comparing Regional Security Complexes in the Western Balkans and the Horn of Africa}

At first glance, the two regions examined have significant dissimilarities; the Horn of Africa is characterised by on-going conflict and insecurity, while the Western Balkans constitute a post-conflict stabilisation scenario. However, both are regional security complexes. That is, geographic areas where the security of one actor interacts with that of others. ${ }^{4}$ In both regions, such security interdependence is intense and must be appreciated and appropriately addressed to prevent further insecurity. Throughout both regions authoritarian regimes and power politics undermine governance. Governments across these areas stand accused of suppressing minority groups and views. This creates challenges both within and between countries, as political elites fuel inter-group grievances to gain and retain power. Both the Western Balkans and the Horn of Africa face problems of democratic deficit, unequal economic development and limitations to civic, human and

3 Rodt 2017 develops effectiveness criteria for civilian CSDP missions with a preventive purpose and indicators by which to evaluate them. That analytical framework has been adjusted and applied for the purpose of this research through the development and application of the four research questions articulated above.

4. Buzan and Wæver 2003. 
minority rights. Thus, it is important in both cases to sustain external support for state and institution building, particularly with regard to the provision of security and the rule of law. ${ }^{5}$

Ruling elites in both regions prove unable and unwilling to represent their populations as a whole, alienating rather than standing accountable to their citizenry. As a result, states struggle to secure and control their full territories and ensure that institutions reach and represent all people. Gaps between governments and parts of their populations contribute to continued disputes over legitimate rule and regulation. The state itself has become a bone of contention, as politics have become a zero-sum game. This has repeatedly led to violence, as different groups have fought for rights, recognition and representation. In the slipstream hereof, organised crime challenges countries in both regions, whether this materialises in illicit trade of people, goods and services or other criminal enterprises such as piracy, terrorism or recruitment of foreign fighters. These problems are connected and exacerbated at the regional level as insecure borders allow criminal networks and activities to operate across national and international boundaries. National security problems must therefore be solved with regard to the broader region, just as regional approaches must deliver on the ground. ${ }^{6}$

In sum, the Western Balkans and the Horn of Africa experience similar causes and consequences of conflict, although they differ significantly in the degree to which these challenge local, national and regional security - let alone European stability. The findings of this first part of the analysis illustrate the importance of international actors like the EU neither undermining regional security in favour of national security nor vice versa, but working actively to promote security at all levels, simultaneously addressing causes and consequences of conflicts to prevent further violence both within and between countries. Therefore, the following looks first at regional and then national level EU responses in order to determine whether they serve needs on the ground.

\section{EU Regional Strategies for Security Provision in the Western Balkans and the Horn of Africa}

The EU has framed its approach to preventing further violent conflict in the Western Balkans as a regional Stabilisation and Association Process. This has allowed the EU to promote, support and reward conflict prevention in the region, whilst addressing its own concerns regarding security and serious crimes on and across its borders in South Eastern Europe. The kingpin of this process is the promise of further European integration for the countries in the region, which has motivated progress through a combination of push and pull factors. Integrating conflict prevention into the wider European integration process in these countries has made much progress. However, security challenges remain and the EU's regional strategy of stabilisation through association requires that the member-

$5 \quad$ Rodt et al. 2017.

6 Ibid. 
ship prospect remains credible, as demonstrated by the way in which enlargement fatigue within the Union translates into reform reluctance outside it. ${ }^{7}$

The EU Strategic Framework for the Horn of Africa similarly takes a regional approach towards providing security and preventing conflict in that region. Within this Framework the EU has integrated its policies promoting security and development, seeking to strengthen institutions, governance and the rule of law to counter challenges like piracy and terrorism, both by seeking to eradicate specific groups and reducing structural causes of insecurity such as government instability, socioeconomic inequality and unemployment. The EU seeks to increase cooperation with as well as between and within these countries and to strengthen regional governments, organisations and solutions. At present, however, Horn governments with limited reach and enforcement capabilities such as the Federal Government of Somalia can handle neither terrorism nor piracy without assistance, nor do they have the ability to prosecute and reintegrate apprehended criminals or prevent further violence and conflict. This illustrates a gap between EU strategic ambitions and realities on the ground, similar to that in the Western Balkans. ${ }^{8}$

In response to some of the specific challenges identified above, the EU has sought to support its strategic approaches towards both regions through a series of CSDP deployments. These have focused in particular on strengthening security structures through police, military and rule of law missions. Regional reviews of these efforts are synthesised in Table 1 and 2.

$7 \quad$ Rodt et al. 2017.

8 Ibid. 


\begin{tabular}{|c|c|c|c|c|}
\hline $\begin{array}{l}\text { Mission/ } \\
\text { operation }\end{array}$ & $\begin{array}{l}\text { Deploy- } \\
\text { ment }\end{array}$ & Mandate & Country & Capacity \\
\hline $\begin{array}{l}\text { EU Police Mis- } \\
\text { sion - EUPM- } \\
\text { BiH }\end{array}$ & $\begin{array}{l}2003- \\
2012\end{array}$ & $\begin{array}{l}\text { (i) Strengthening the operational capacity and } \\
\text { joint capability of the agencies engaged in the } \\
\text { fights against organised crime and corruption, } \\
\text { (ii) assisting and supporting in the planning and } \\
\text { conduct of investigations in the fight against } \\
\text { organised crime and corruption in a systematic } \\
\text { approach, (iii) assisting and promoting develop- } \\
\text { ment of criminal investigative capacities of BiH, } \\
\text { (iv) enhancing police-prosecution cooperation, } \\
\text { (v) strengthening police-penitentiary system } \\
\text { cooperation and (vi) contributing to ensuring a } \\
\text { suitable level of accountability. }\end{array}$ & $\begin{array}{l}\text { Bosnia and Her- } \\
\text { zegovina }(\mathrm{BiH})\end{array}$ & $\begin{array}{l}\text { Initial mission } \\
\text { strength in January } \\
\text { 2003: } 478 \text { interna- } \\
\text { tional staff and } 296 \\
\text { national staff } \\
\\
\text { Mission strength } \\
\text { in June 2012: } 34 \\
\text { international staff } \\
\text { and } 49 \text { national }^{9}\end{array}$ \\
\hline $\begin{array}{l}\text { EU Military } \\
\text { Operation } \\
\text { - Concordia } \\
\text { FYROM }\end{array}$ & 2003 & $\begin{array}{l}\text { Supporting FYROM in its implementation of } \\
\text { the Ohrid Agreement, ending the hostilities } \\
\text { between armed ethnic Albanian groups and } \\
\text { FYROM security forces. }\end{array}$ & $\begin{array}{l}\text { Former Yugoslav } \\
\text { Republic of } \\
\text { Macedonia } \\
\text { (FYROM) }\end{array}$ & $\begin{array}{l}375 \text { personnel in } \\
\text { March } 2003^{10}\end{array}$ \\
\hline $\begin{array}{l}\text { EU Police Mis- } \\
\text { sion - EUPOL } \\
\text { Proxima FY- } \\
\text { ROM }\end{array}$ & $\begin{array}{l}2003- \\
2005\end{array}$ & $\begin{array}{l}\text { Support (i) consolidation of law and order, } \\
\text { including the fight against organised crime, (ii) } \\
\text { practical implementation of the comprehen- } \\
\text { sive reform of the Ministry of Internal Affairs, } \\
\text { including the police, (iii) operational transition } \\
\text { and creation of a border police, (iv) local police } \\
\text { in building confidence within population and } \\
\text { (v) enhanced co-operation with neighbouring } \\
\text { states in the field of policing. }\end{array}$ & $\begin{array}{l}\text { Former Yugoslav } \\
\text { Republic of } \\
\text { Macedonia }\end{array}$ & $\begin{array}{l}\text { Approximately } \\
200 \text { personnel in } \\
\text { December } 2003^{11}\end{array}$ \\
\hline $\begin{array}{l}\text { EU Police As- } \\
\text { sistance Team - } \\
\text { EUPAT FYROM }\end{array}$ & 2006 & $\begin{array}{l}\text { Succeeded EUPOL Proxima in monitoring and } \\
\text { mentoring mid- and senior level police officers. } \\
\text { Focus on border police, public peace, order, } \\
\text { accountability and the fight against corruption } \\
\text { and organised crime. }\end{array}$ & $\begin{array}{l}\text { Former Yugoslav } \\
\text { Republic of } \\
\text { Macedonia }\end{array}$ & $\begin{array}{l}\text { Approximately } 30 \\
\text { personnel in } 2006^{12}\end{array}$ \\
\hline $\begin{array}{l}\text { EU Military } \\
\text { Force - EUFOR } \\
\text { ALTHEA }\end{array}$ & $\begin{array}{l}2004- \\
\text { ongoing }\end{array}$ & $\begin{array}{l}\text { (i) To provide support via Collective and Com- } \\
\text { bined Training in order to support the ability } \\
\text { of the BiH Armed Forces to sustain interna- } \\
\text { tional standards, }{ }^{13}(\mathrm{ii}) \text { to support } \mathrm{BiH} \text { efforts to } \\
\text { maintain the safe and secure environment in } \\
\text { BiH and (iii) to provide support to the overall } \\
\text { EU comprehensive strategy for } \mathrm{BiH} \text {. }\end{array}$ & $\begin{array}{l}\text { Bosnia and } \\
\text { Herzegovina }\end{array}$ & $\begin{array}{l}600 \text { personnel in } \\
\text { January } 2015^{14}\end{array}$ \\
\hline $\begin{array}{l}\text { EU Rule of Law } \\
\text { Mission - EU- } \\
\text { LEX KOSOVO }\end{array}$ & $\begin{array}{l}2008- \\
\text { ongoing }\end{array}$ & $\begin{array}{l}\text { To assist and support the Kosovo authorities in } \\
\text { the rule of law area, specifically in the police, } \\
\text { judiciary and customs areas. }\end{array}$ & Kosovo & $\begin{array}{l}\text { Authorised maxi- } \\
\text { mum strength: } 800 \\
\text { international and } \\
800 \text { local personnel }^{15}\end{array}$ \\
\hline
\end{tabular}

9 EEAS 2012.

10 Ladzik 2009, 2.

11 EUPOL Proxima 2003.

12 EU Council Secretariat 2005.

13 This mandate ended in 2018.

14 EEAS 2015a.

15 EEAS 2014b. 
Table 1: Regional review of CSDP missions deployed in the Western Balkans ${ }^{16}$

\begin{tabular}{|c|c|c|c|c|}
\hline Mission/operation & Deployment & Mandate & Country & Capacity \\
\hline $\begin{array}{l}\text { EU Naval Force - } \\
\text { NAVFOR Operation } \\
\text { Atalanta }\end{array}$ & 2008-ongoing & $\begin{array}{l}\text { (i) Protect vessels from World Food } \\
\text { Programme, African Union Mission } \\
\text { in Somalia (AMISOM) and other } \\
\text { vulnerable shipping, (ii) deter and } \\
\text { disrupt piracy, (iii) monitor fishing } \\
\text { activities and (iv) support other } \\
\text { EU missions and activities of other } \\
\text { international organisations in the } \\
\text { region. }\end{array}$ & Coast of Somalia & $\begin{array}{l}\text { Changes during } \\
\text { the year but } 1000 \\
\text { personnel overall }^{17}\end{array}$ \\
\hline $\begin{array}{l}\text { EU Training Mission } \\
\text { - EUTM Somalia }\end{array}$ & 2010-ongoing & $\begin{array}{l}\text { Initially training Somali forces. Later } \\
\text { mandate was refocused to training } \\
\text { of personnel at the political and } \\
\text { military strategic level within Somali } \\
\text { defence institutions. }\end{array}$ & $\begin{array}{l}\text { First Uganda, then } \\
\text { Somalia from } 2014\end{array}$ & $\begin{array}{l}203 \text { personnel in } \\
\text { January } 2019^{18}\end{array}$ \\
\hline $\begin{array}{l}\text { EU Maritime } \\
\text { Security Capacity } \\
\text { Building Mission in } \\
\text { the Horn of Africa } \\
\text { and Western Indian } \\
\text { Ocean- EUCAP } \\
\text { NESTOR, later } \\
\text { EUCAP Somalia }\end{array}$ & 2012-ongoing & $\begin{array}{l}\text { To establish and capacity build } \\
\text { maritime civilian law enforcement } \\
\text { capability in HoA and Western } \\
\text { Indian Ocean (later only in Somalia) } \\
\text { by assisting authorities in carrying } \\
\text { out coast guard functions and } \\
\text { policing of the coastal zone on land } \\
\text { and at sea. }\end{array}$ & $\begin{array}{l}\text { Somalia, Djibouti, } \\
\text { Seychelles and } \\
\text { Tanzania. From } \\
2015 \text { the focus } \\
\text { has been solely on } \\
\text { Somalia }\end{array}$ & $\begin{array}{l}81 \text { international } \\
\text { staff and } 18 \\
\text { national in May } \\
2019^{19}\end{array}$ \\
\hline
\end{tabular}

Table 2: Regional review of CSDP missions deployed in the Horn of Africa ${ }^{20}$

16 Rodt et al. 2017, 97-98 (revised).

17 Two surface combat vessels and 2 Maritime Patrol and Reconnaissance Aircrafts in May 2019. EUNAVFOR Somalia no date.

18 EEAS 2017a.

19 EEAS 2017b.

20 Rodt et al. 2017, 95 (revised). 


\section{Comparative Case Study of EULEX Kosovo and EUCAP Nestor/Somalia}

This next part of the analysis examines whether, and if so how, two specific CSDP missions have helped the EU achieve what it set out to do in its regional strategies to prevent further insecurity in the Western Balkans and Horn of Africa. In so doing, it performs a structured, focused comparison of EULEX Kosovo and EUCAP Nestor/Somalia. Kosovo and Somalia constitute particularly pressing and complex challenges in their respective regions and are illustrative examples of how local, national, regional and international levels of security are interdependent. The CSDP missions are the Union's practical response to those challenges. Moreover, they have been selected, as they are recent, ongoing and extensive missions; cases where the EU has practically sought to implement strategies, focus activities and apply resources to prevent further insecurity in each of the two regions. They are representative cases of civilian CSDP missions deployed to build local capacity to prevent further insecurity. At the same time, each in their own way, they are unique and a first of their kind, representing a continued EU ambition to respond to local realities. As such, they are and can be expected to have had a significant impact on the ground.

The European Union Rule of Law Mission in Kosovo, known as EULEX, was launched in February 2008. Ten years on it remains the largest civilian CSDP mission to date and the only one with an executive mandate to directly implement rule of law. ${ }^{21}$ Its aim is to aid and assist Kosovo authorities to implement rule of law specifically with regard to the police, judiciary and customs, preferably through monitoring, mentoring and advising (MMA), but retaining - where this is deemed appropriate - executive responsibility and authority. ${ }^{22}$ The current mandate covers the period until 14 June $2020 .^{23}$ The European Union Maritime Security Capacity Building Mission in the Horn of Africa and Western Indian Ocean was launched in July 2012 as the first civilian maritime mission operating across a number of countries in a region. Activities in Djibouti, Seychelles and Tanzania have since been phased out and Headquarters relocated to Somalia in 2015. When the mandate was renewed in December 2016, the mission renamed EUCAP Somalia re-focused on strengthening that country's maritime security capacity. ${ }^{24}$ In 2018 , this mandate was extended until December $2020 .^{25}$

21 Council of the European Union 2008.

22 van der Borgh 2016.

23 EULEX 2019.

24 Council of the European Union 2012; EUCAP Somalia 2017.

25 Council of the European Union 2018. 


\section{Operational Effectiveness from an EU Perspective}

The comparative case study of the two CSDP missions is structured and focused by four research questions. It begins by applying an EU perspective and asking (a) whether each mission achieved the Union's strategic goals and operational objectives (b) in a timely, efficient and cost-effective manner.

\section{Has EULEX Kosovo achieved the EU's strategic goals and operational objectives?}

EULEX was launched with a mandate to: "Assist the Kosovo institutions, judicial authorities and law enforcement agencies in their progress towards sustainability and accountability and in further developing and strengthening an independent and multi-ethnic justice system and a multi-ethnic police and customs service, ensuring that these institutions are free from political interference and adhering to internationally recognised standards and European best practices". EULEX was tasked to support capacity building in Kosovo's judicial institutions and law enforcement agencies through monitoring, mentoring and advising, while at the same time, it was the first CSDP mission with executive powers to investigate, prosecute, adjudicate and enforce law. ${ }^{26}$

From an EU perspective, this mission was ambitious. Its strategic goals were high and its operational objectives were difficult to obtain. The mandate was criticised by a European Court of Auditors (ECA) review, which deemed it too broad, especially as it was not broken down into clear benchmarks and verifiable indicators. ${ }^{27}$ According to the ECA, this left operational objectives unclear and made achieving, monitoring and evaluating progress difficult. EULEX's mandate to implement internationally recognised standards and European best practices created further confusion as not all EU member states had reached the same standards or shared practices. ${ }^{28}$ A later review suggested that the EU would have to dedicate itself to this process for decades to come, if Kosovo was to reach the highest international levels or European best practices of jurisprudence. ${ }^{29}$ A third challenge presented by the mandate was its lack of clarity concerning when the mission's executive power would take over from its supporting functions - and vice versa - leaving

26 This could be done by international investigators, prosecutors and judges in cooperation with their Kosovo counterparts or independently and might include arrests of suspects or riot policing without prior consultation with Kosovo Police (KP), if it was considered to have failed to provide effective first response. EULEX's executive mandate included the power to reverse or annul operational decisions taken by Kosovo authorities, if this was deemed necessary for the maintenance and promotion of rule of law, public order and security. The executive mandate specifically concerned war crimes, terrorism, organised crime, corruption, inter-ethnic crimes, financial and economic crimes and other so-called serious crimes (Council of the EU 2008).

27 ECA 2012, 26.

28 Interview 1.

29 Jacqué 2015, 16. 
it unclear when host authorities were deemed ready to perform their duties only with support from EULEX and when they were not. ${ }^{30}$

Despite the difficulties identified in the mandate, both former and current EULEX employees argued that the mission's broad competencies were appropriate. Key persons accused of war crimes, in their experience, were often simultaneously involved in organised crime and corruption, wherefore evidence could not be collected properly without examining the linkages between them. ${ }^{31}$ Some stressed that the executive mandate was especially important in investigating and prosecuting war crimes, as internationals were deemed less likely to be partial or corrupt in an area, where vast vested interests were at stake and may obstruct justice. ${ }^{32}$ While this is not necessarily the case, in order for a rule of law mission to be implemented successfully, primary data suggests that it was rightfully designed to include all elements of investigation, prosecution and adjudication, although these should have been better integrated from the beginning.

The EULEX mission itself lists as its key achievements: first, the strengthening effort to train Kosovo police; second, advice and material support for the establishment and management of border crossings points; third, support and advice to the Kosovo Judicial and Prosecutorial Council; and fourth, legislative assistance and support to other structural reforms. This indicates some success towards achieving its mandated goals to assist Kosovo's judiciary, police and customs. Independent mid-mission reviews similarly conclude

30 EULEX personnel explained how initially international investigation, prosecution and adjudication were separate from domestic parallel processes, thus, preventing EULEX staff from coaching host country law enforcement and judicial professionals during their execution of these tasks. While this was explained by a fear of corruption and information leaks, it should not, they argued, have prevented better coordination between the Executive and Strengthening Divisions of the mission to promote shared models of governance for Kosovo's law enforcement and judicial institutions. This might in turn have allowed for a smoother transition between executive and capacity-building functions. EULEX staff recommended that future missions link executive and capacity-building functions in one combined effort from the beginning. Interviews 2, 3 and 4. A EULEX staff member indicated that the ECA criticism was perceived internally as a recommendation to transfer competencies from the Executive to the Strengthening Division and to lower staff numbers, so as to imply success in certain mission areas. The interviewee suggested, however, that this was unrealistic, because of the resources required to complete the tasks leftover. The example given was the cut of an integrated border management (IBM) component from the Executive Section during a 2016 revision of the mandate. This decision by member states left the task of monitoring border posts in Northern Kosovo to the Strengthening Division. With only one expert for IBM and four advisors in the North, they struggled to meet local demands, e.g. attending joint weekly meetings of Kosovo and Serbian police, who would not meet without EULEX. "There are three meetings a week in 15 border crossings, so how can freedom of movement be implemented, if EULEX does not support [Kosovo and Serbian border police services] talking?" Interview 2.

31 Interview 2 and 4.

32 Interview 3 and 4. 
that EULEX has fulfilled parts of its mandate, but tend to see the glass as half-empty rather than half-full. ${ }^{33}$

Subsequent to external criticism regarding the lack of mission monitoring and evaluation, EULEX introduced a new 'programmatic approach' for the first time in any CSDP mission, tasking the Strengthening Division to monitor the progress of host institutions against strategic objectives agreed by EU member states. ${ }^{34}$ The most effective capacitybuilding effort proved the development of the customs service, due in part to the consistency of international assistance, which was led and supervised by only one European actor - the UK - for almost two decades, deploying key personnel in the United Nations Mission in Kosovo (UNMIK) and EULEX. ${ }^{35}$ This illustrates how the effectiveness of one actor is always connected to that of others and must be evaluated as such.

Following the mid-mission reviews, EULEX also started measuring the performance of its executive functions by the number of new indictments made and actions completed. By 2016,EULEX listed the following indicators of progress: delivery of approximately 620 verdicts; completed investigations of 250 war crime cases and involvement in the proceedings of ca. 1,350 other cases; adjudication in over 42,700 property related cases and excavation of alleged mass graves. ${ }^{36}$ Published judgments in serious and complex cases are considered a particularly important EULEX legacy for the Kosovo judiciary to follow in future adjudications. ${ }^{37}$ However, due to a high turnover of staff, there has been a backlog of cases, many of which were transferred to national authorities after the 2014 mandate

33 "Assistance has made only a modest contribution to building the capacity of the Kosovo police and little progress has been made in the fight against organised crime. In the judicial sector assistance has been useful but the judiciary continues to suffer from political interference, inefficiency and a lack of transparency and enforcement. EU interventions have had only limited results in tackling corruption, which continues to prevail in many areas. Most progress was made in the area of customs. There has been almost no progress in establishing the rule of law in the North of Kosovo. Overall, the sustainability of results which have been achieved by the assistance is threatened by a lack of political will, weak financial capacity and the limited influence of civil society." ECA 2012, 35. Three years on, another review pointed to a lack of progress in the fight against corruption and organised crime, highlighting continued corruption in the judiciary and a culture of political interference in law enforcement and judicial processes as especially challenging tasks ahead. Jacqué 2015,17 . Local experts have expressed similar concerns. Kursani 2013.

34 As explained by EULEX (no date): "The central aim is to ensure accountability and to statistically measure the achievements of EULEX, by measuring the progress of the local rule of law institutions". These activities were frequently overlapping with the European Commission's pre-accession assistance for institution building, as well as a number of other international activities in the field. The effectiveness of capacity-building is linked to several international actors supporting local institutions and the consistency of approaches and coordination of efforts that they have developed in collaboration with local counterparts.

Welski 2014.

36 quoted in Zupančič et al. 2016, 28.

37 Interview 2. 
revision..$^{38}$ Despite the importance of EULEX staff investigating some of the most difficult war crimes cases, the mission has had a mixed record also in this regard, as it has not completed many major cases concerning crimes allegedly committed in the immediate aftermath of the Kosovo conflict. These deficiencies reflect problems in mission planning and deployment, as well as the environment in which the mission operates. ${ }^{39}$

Most interlocutors interviewed for this study suggested that the Kosovo Police had more capacity due to the longer-term investment by the international community. ${ }^{40}$ In contrast, Kosovo's judicial system is still an amalgamation of international judges (initially from UNMIK, later EULEX); judges recruited from the former Yugoslav judiciary; and newly enrolled ones. ${ }^{41}$ The discussion of challenges encountered when using international police and judges to develop capacities of local institutions is important for future missions. National policing styles are considered less diverse than national judicial practices. ${ }^{42}$ In effect, all interviewees agreed that the judiciary is the most difficult area of institutional capacity to develop for both the host country and the countries deploying capacity-building assistance, due to the difficulty of recruiting experienced staff and the absence of an agreed-upon EU model in this area. Therefore, in comparison to their capacity building efforts with the police, internationals have created more confusion in the judiciary, where core legislation was developed in line with continental European or Anglo-Saxon case law depending on which actor had more influence at a given moment. ${ }^{43}$ Diversity in different national judicial cultures also had an effect in the executive part of the EULEX mission, as

38 The 2012 ECA stressed that such a mission should have sufficient and sustained human and material resources at its disposal from the beginning to ensure uninterrupted functioning. EULEX staff members similarly suggest that if such an ambitious mission were to be implemented again, member states should guarantee a longer commitment, i.e. mandate, to the mission. They estimate that at least a decade is required to get a final verdict in complex cases regarding organised crime and war crimes. "It takes a few years to investigate a complex crime in a foreign country and to collect enough evidence for the trial. Then the first instance trial usually takes another two to three years, followed by a few years for 2nd instance trial and if there is re-trial it can take ten to fifteen years to get final decisions in complex cases". Interview 2 . The EULEX mission has now completed its tenth year in action. However, the extension of its mandate was not guaranteed from the beginning, but required approval by the Council and host government every two years. This lack of predictability in the duration of the mandate led to staff disengagement. "Everybody is looking for a new job a year before expiry of the mandate, so that is usually the year when we have biggest turn-over of staff". Interview 2. Due to expectations that the current extension may be the last one and that EULEX may leave Kosovo, there is an impression that "major cases are pending as they [Kosovo institutions] are waiting for us to go". Gjyshinica, 2016.

39 Capussela 2015; ECA 2012, 62-66. Interview 3, among others, listed challenges such as witness protection in a closely intertwined society such as Kosovo and political obstructions by local political elites and suggested that systems put in place in Bosnia and Herzegovina were more effective in protecting witnesses and providing support to victims.

40 Interview 1,2 and 5.

41 Welski 2014.

42 Interview 4.

43 Ibid. 
different judicial practices were exercised in the absence of a common understanding of 'highest European standards.'

So, did EULEX Kosovo achieve the EU's strategic goals and operational objectives? In part, the mission has had some success in achieving its overall aims, and although operational objectives were unclear in the beginning EULEX prides itself on specific achievements. Nevertheless, the Union has struggled to achieve all that it set out to do to support the provision of security through rule of law in Kosovo. The next question, therefore, is: why?

\section{Has EULEX Kosovo's implementation been timely, efficient and cost-effective?}

EULEX was slow to deploy. This was primarily caused by political differences among EU member states regarding the legal status of Kosovo and in effect EULEX. ${ }^{45}$ A second factor that limited the timeliness of EULEX implementation in Kosovo relates to inadequacies in member states' capability for rapid and flexible deployment of competent civilian - especially judicial - staff. A third factor negatively impacting the timely implementation of this mission was the inadequate programming and procurement system of the European Commission, which did not allow for timely procurement responding to operational needs. ${ }^{46}$

With regard to the efficiency of the mission, there have been two major sets of challenges. The first was related to human resources. ${ }^{47}$ Major staffing challenges and significant staff turnover led to a lack of consistency within the mission and in its relations with other actors. ${ }^{48}$ From the beginning, EULEX struggled to recruit the right number of staff with the relevant expertise. A EULEX employee highlighted how it is difficult to recruit the

44 For example, in some EU countries informal meetings between judges and prosecutors are standard practice, while in others this is seen as interference in due process. Jacqué 2015, 17.

45 An EU Planning Team (EUPT) was deployed to Kosovo in 2006. It was replaced by EULEX two years later, twice the average time for mission deployment. The key reason for this delay being the wrongful assumption that the Ahtisaari plan for the future legal status of Kosovo would be adopted by the UN Security Council (UNSC), enabling the EU to take over all competencies from the UN Mission in Kosovo. However, once the Ahtisaari plan was blocked by Russia in the UNSC and Kosovo subsequently declared its independence unilaterally, EU member states disagreed on the desired end-state towards which they wanted Kosovo and its institutions to develop. A compromise was found by allowing EULEX to deploy in line with UNSC Resolution 1244 and function in parallel rather than as the successor to UNMIK. Having a separate planning mission preparing a complex mission like EULEX is good practice, however, future planning missions should be realistic and where necessary develop different operational options for various possible political scenarios. Grilj and Zupančič 2016, 68-71.

46 Procurement rules are slow, cumbersome and not adequate for this type of mission. In the words of one former EULEX employee, the procurement system "did not understand that court cases could not fit in the box." Interview 3; ECA 2012, 28.

47 ECA 2012; Jacqué 2015, 18-19, Interview 3, who has worked in several CSDP missions noted that: "the biggest problems of CSDP and EEAS is recruitment, retention and firing (...) lack of a functioning human resources management system".

48 ECA 2012. 
right profile of staff with sensitivity for transitional justice issues and experience of dealing with all phases of investigation, prosecution and adjudication of serious and 'high politics' crimes such as war crimes and organised crime. ${ }^{49} \mathrm{~A}$ further problem related to human resources is short secondments, as most member states do not support individual deployments longer than three and a half years. In fact, many secondments are only one year, which typically motivates junior rather than senior staff to apply. ${ }^{50}$ These problems were exacerbated by the requirement for all staff to go through another selection process after the 2010 mission review. ${ }^{51} \mathrm{~A}$ second cause of EULEX inefficiency was related to coherence of action with other EU actors present in Kosovo - primarily the EU office and its political and developmental sections.

The lack of coherence among EU institutions, actors and tools limited not only the efficiency but also the cost-effectiveness of EULEX. There were major coordination challenges between the EU Office and EULEX, as they were both supporting rule of law in Kosovo - EULEX through its executive and MMA functions since 2010, and the EU Office from 2000 (and later through IPA). This overlap was partially caused by inadequate mission planning, as the EULEX planning document did not contain an exit strategy, objective benchmarks to measure progress or a plan for handing over responsibility for capacity-building to the EU Office or any other international actor. ${ }^{52}$ Related to this was the lack of a joint capacity-building concept among EU actors present in the field. The coherence of EU assistance was undermined by the absence of consensus between EU member states regarding Kosovo's independence and the types of mandates that should be held by Kosovo's institutions. By filling EU posts predominantly through secondments, it was frequently left to national experts involved in capacity-building efforts to choose models to be promoted in the Kosovo institutions. The lack of clarity on what best European standards are in the judiciary also negatively affected the executive function. ${ }^{53}$ The ECA review found in the same vein that intra-EU political coordination and guidance was not fully ensured through the establishment of the EU Special Representative (EUSR)..$^{54}$ This resulted in limited coherence in political messaging from different EU stakeholders towards the host government and population, as coordination depended greatly on the personal relationship between the EUSR and the Head of EULEX. ${ }^{55}$ EULEX's impact is widely perceived as mostly positive when it comes to support provided to structured EU initiatives such as the Belgrade-Pristina Dialogue and the visa liberalisation process, "which would otherwise be difficult to implement" without operational human resources

49 Interview 2.

50 Ibid., 31: Jacqué 2015, 18.

51 Interview 3.

52 ECA 2012, 29.

53 Jacqué 2015, 17.

54 ECA 2012.

55 Interview 2. 
deployed in the field. But here too there is space for greater coordination and coherence among different EU actors under the EUSR. ${ }^{56}$

In sum, lack of consensus among EU member states on Kosovo and in effect EULEX caused the mission's struggles to implement its ambitious mandate in full in a timely, efficient and cost-effective manner. EULEX has become more effective from an EU perspective in the second half of its mandate, as it has made a series of adjustments following external criticism, but it still experiences significant challenges when it comes to staffing, transition from executive to supporting functions and implementing an overall coherent approach with other EU actors in Kosovo.

Has EUCAP NESTOR/Somalia achieved the EU's strategic goals and operational objectives?

Similarly to its approach in the Western Balkans and as stated in the Strategic Framework for the Horn of Africa, the European Union's interests in the Horn are: "defined by the region's geo-strategic importance, the EU's historic engagement with the countries in the region, its desire to support the welfare of the people and help lift them from poverty into self-sustaining economic growth, and the need for the EU to protect its own citizens from the threats that emanate from some parts of the region and address common challenges". ${ }^{57}$ To this end, CSDP priorities for security provision in the Horn of Africa have been piracyfocused. In June 2008, the UNSC adopted Resolution 1816, which authorised third party states to enter the territorial waters of Somalia and to use all means necessary to combat piracy. The EU launched its first naval counter-piracy operation, NAVFOR Atlanta, off the coast of Somalia in December 2008. Drawing on the Strategic Framework for the Horn of Africa, which called for a regional approach, the Union launched EUCAP Nestor in July 2012 with an initial budget of $€ 11.9$ million. ${ }^{58}$ EUCAP Nestor was the first civilian CSDP mission to have a regional focus. ${ }^{59}$ It was created to complement simultaneous EU operations, EUNAVFOR Atlanta and the EU Military Training Mission in Somalia. ${ }^{60}$ EUCAP Nestor also worked alongside other regional and international actors operating in

56 IECEU roundtable of experts: Balkans 2016.

57 Council of the European Union 2011b, 4.

58 Council of the European Union 2011a; Council of the European Union 2012.

59 Tejpar and Zetterlund 2013, 9.

60 EEAS 2016d. 
the Horn of Africa, including the United Nations, ${ }^{61}$ the Intergovernmental Authority on Development (IGAD), the African Union (AU), the International Maritime Organisation $(\mathrm{IMO})^{62}$ and Oceans Beyond Piracy (OBP). ${ }^{63}$

EUCAP Nestor was initially mandated to operate in four countries: Djibouti, Somalia, Seychelles and Tanzania. After a comprehensive review undertaken by the EU in 2015 the mission, renamed EUCAP Somalia, was reframed to focus solely on that country. EUCAP's redefined aim is to bolster Somalia's maritime security force, strengthen its ability to fight piracy and increase its overall capacity to patrol its territorial waters. ${ }^{64}$ Its core objective is to build capacity to cover the entire process of prosecuting acts of piracy "from crime to court". ${ }^{5}$ In pursuit of this purpose, EUCAP was intended to work with key maritime security actors within Somalia, including the coast guards, navy, police forces, judges and prosecutors. ${ }^{66}$ Together, EUCAP experts and their Somali counterparts were to improve "existing legal and law enforcement frameworks related to anti-piracy and [to develop] relevant maritime security capacity instruments". ${ }^{67}$

In order to fulfil its aims, EUCAP provides advice, mentoring and training in three areas of expertise: legal, maritime and policing. EUCAP facilitates basic coast guard training as well as expert training in diverse fields from law drafting to engineering. EUCAP experts have been placed within local maritime security authorities in order to provide additional support and guidance and to assist in the development of organisational structures. ${ }^{68}$ In the European External Action Service's own words: "Strategic level advice is complemented by the coordination and facilitation of specialised training to support capacity-building efforts". ${ }^{9}$

61 The United Nations is very active in the Horn of Africa. Of particular note is the United Nations Assistance Mission in Somalia (UNSOM) and the United Nations Development Programme (UNDP). UNSOM was established on 3 June 2013. It provides policy advice to the Somali government and to the African Union Mission in Somalia (AMISOM) in a variety of areas, including governance, democratisation, security and donor relations (UNSOM, no date). UNDP is the UN's global development network and mainly concentrates on sustainable development, democratic governance and peacebuilding, climate change and disaster resilience (UNDP, no date).

62 IMO is a UN agency dedicated to safeguarding and securing international shipping as well as working to end pollution from ships (IMO, no date).

63 OBP is a non-profit organisation that was formed in 2010 to '[mobilise] stakeholders from the maritime community, [develop] public-private partnerships to promote long-term solutions at sea and ashore [and to create] sustainable deterrence based on rule of law (OBP, no date). EEAS 2016d.

64 Ibid.

65 EEAS 2014b.

66 Ibid.

67 Ibid.

68 Ibid.

69 EEAS 2016d. 
EUCAP's greatest achievements are related to its training and workshop programmes provided throughout the Horn of Africa. Partnering with local and international experts, EUCAP has facilitated trainings on both theoretical and practical aspects of maritime security. These trainings have been successful both in terms of operational objectives related to skills and knowledge transfers, but also by increasing cooperation between EUCAP and regional actors as well as between the regional actors themselves as per the EU's strategy. Additionally, trainings were conducted using a variety of EUCAP Nestor staff from trainers and experts from Seychelles and Djibouti to navy and coast guard personnel from a number of countries both within and outside the Horn. ${ }^{70}$

Nevertheless, from an EU perspective, EUCAP has a mixed record so far. As a civilian CSDP mission, it has advanced the EU's overall strategic goal of strengthening the soft capacity of navies, coast guards and police forces, as well as criminal and legal justice systems in the region. Furthermore, EUCAP has successfully achieved internal EU objectives such as empowering locals through capacity development and training. However, looking at the impact on piracy reduction off the coast of Somalia, a strategic goal for the Union, EUCAP has not been as directly effective as other EU operations such as NAVFOR Atalanta. The subsequent sections will explain why.

\section{$\underline{\text { Has EUCAP Nestor/Somalia's implementation been timely, efficient and cost-effective? }}$}

Contrary to the EULEX experience in Kosovo, contributing to EUCAP's achievements in Somalia has been its efforts to complement other EU actions in the region. "Together, EUCAP NESTOR, Atalanta and EUTM form a coherent, integrated CSDP package supporting the EU's Strategic Framework for the Horn of Africa". ${ }^{71}$ While this has been accomplished in several ways, two areas stand out. First, EUCAP Nestor and EUNAVFOR Atalanta's mandates complement each other with both supporting the EU's strategic goals for peace and stability in the region. The two missions do this in different focus areas and through different approaches, but both support capacity-building specifically with regard to maritime security provision. ${ }^{72}$ Second, EUCAP Nestor and Atalanta have supported each other in practical terms. Representatives from the two missions frequently visit one

70 One example of a successful training was the 2013 maritime security course for 14 high-level individuals on board the HNLMS Johan de Witt. The training focused on building leadership capabilities and increasing knowledge of maritime legal matters through learning sessions and practical exercises. A second example was a training session co-hosted by EUCAP Nestor and the Federal Government of Somalia in 2015. This workshop included individuals from across Somali regional governments and law enforcement agencies as well as representatives from international stakeholders such as UNSOM, EUNAVFOR, EUTM Somalia and the UK embassy. The workshop served as a forum to continue "enhancing and strengthening knowledge, understanding, cooperation and cohesion among the different maritime-security entities in Somalia." EEAS 2015.

71 EEAS no date.

72 Tejpar and Zetterlund 2013. 
another and attend similar events as well as planning joint activities such as trainings. ${ }^{73}$ The complementary nature of EUCAP Nestor and other EU activities in the region, particularly EUNAVFOR Atalanta, is a strong feature in EUCAP Nestor's implementation and provides an example of coordination potentially to be reproduced by other missions or in other areas.

While EUCAP Nestor's training programmes have had some success, the long-term sustainability of its trainings is a strategic issue that must be addressed, particularly EUCAP Nestor's focus on 'soft' capacity-building, such as advice and training. This focus is not aligned with the priorities of affected countries and their need for equipment such as boats and weapons or improved coastguard infrastructure. ${ }^{74}$ Thus, while EUCAP Nestor has provided training and knowledge-transfer necessary for capacity-building, its mandate did not include a remit to provide the 'hard' capacity needed to apply the new training and skills. ${ }^{75}$ One EUCAP Nestor official put it this way: "[w] hen you train somebody they pass it on to others in their organisations. If there are no buildings, no operation centres, no schools, there is nothing to maintain this knowledge" ${ }^{76}$

While EUCAP Nestor trainings and advice have achieved internal EU objectives, the mandate's implementation has not been entirely timely, efficient or cost effective. First, many of its early engagements occurred in the broader region, limiting its activities in Somalia, where the piracy problem was focused. Second, despite these early regional efforts EUCAP NESTOR has had limited impact and sustainability in the wider region. Third, many local recipients of EUCAP training lack the necessary equipment and facilities to implement the training, meaning that they are not getting the full benefits of EUCAP NESTOR activities, nor are they able to sustain the actions critical to reducing piracy in the region in the long term. ${ }^{77}$

With these findings in mind, one might question the timeliness of the mission as a whole as well as its efficiency and cost-effectiveness in achieving the EU's strategic goals. The mission was relatively effective in implementing its operational objectives, but this does not necessarily make it timely, efficient and cost-effective from a strategic perspective. This illustrates how the internal EU perspective is linked to the external preventive perspective, as it is in the Union's interest to contribute meaningfully to security provision in the country and region in which it deploys. This leads us to the next part of the analysis, which examines external perspectives on the two missions' effectiveness.

73 EEAS 2016b; EEAS 2016c.

74 Bueger 2013.

75 Ibid.

76 Quoted in Ejdus 2017, 13.

77 Rodt et al. 2017. 


\section{Operational Effectiveness from a Preventive Security Perspective}

Having appraised the two missions from an internal EU perspective, this next section will examine them from an external perspective focused on security provision on the ground. It asks whether each mission has (a) made a meaningful contribution to preventing further insecurity (b) without using disproportionate measures to that end.

\section{Has EULEX Kosovo contributed to preventing further insecurity?}

A 2011 Saferworld survey found the perceived likelihood of renewed conflict in Kosovo decreasing. People felt safer and rightly so. To date, there has been no further violent conflict. The question for this research is whether and if so how EULEX has helped prevent further violence. Saferworld reported generally positive public perceptions of EULEX's impact on law enforcement and justice, in spite of marked frustrations with both sectors and disparities between respondents of different ethnicities. ${ }^{78}$ Civil society representatives interviewed for this study, who consider the mission generally inefficient, inadequate and unaccountable, perceive EULEX less favourably, however. ${ }^{79}$ Overall, it is believed to provide inappropriate support to the Kosovo Police, which is now considered more professional, effective and trusted by larger parts of the population. ${ }^{80}$ Although its reputation has suffered due to political crises and corruption allegations, civil society respondents no longer believe that the Kosovo Police requires the level or kind of support that EULEX provides. ${ }^{81}$

Closer scrutiny reveals that external assessments of EULEX's contribution on the ground depend on the timeframe, location and activities in question. Of the locations where EULEX has operated, it is perceived by civil society representatives to have had the most positive impact on preventing insecurity in the northern regions of Kosovo, where the threat of renewed violence is most significant. ${ }^{82}$ In particular, EULEX is thought to have had a positive effect through its policing mandate and MMA work with police, justice and customs authorities, as well as on court cases related to war crimes and organised crime. ${ }^{83}$ The majority of interviewees suggest that EULEX was most effective in prevent-

78 Saferworld 2011, 28-29.

79 This assessment is based on perception surveys and interviews of representatives of a sample of independent civil society organisations mainly human rights and peacebuilding organisations, women's groups and think tanks. It does not claim to be representative of the whole of Kosovo society. It can also not be claimed that people's perceptions reflected in the surveys fully distinguish EULEX's impact from that of other EU and international activities. Having said that, the mission is widely known by the public and civil society organisations in Kosovo, some of which have actively engaged with the mission. Their answers therefore inform the assessment of external perspectives on EULEX overtime, space and function.

80 Interviews 11 and 12; The Kosovo Police remains the most trusted police force in the region, according to the Kosovo Security Barometer 2016, 8.

81 Interviews 9, 11, 12 and 14.

82 Interviews 9-15.

83 Interviews 9-15. 
ing conflict in areas and at times where the Kosovo Police was unable to deploy, and where tensions between Kosovo Serb and Kosovo Albanian communities were most likely to turn violent. As an executive force and a trusted intermediary between Serbian police and Kosovo state institutions, EULEX played a de-escalatory role through community policing and confidence-building. In particular, the MMA work was viewed as having had a meaningful impact and included input from civil society through regular, thematic and technical consultations. ${ }^{84}$

Perceptions regarding the impact of EULEX's justice mandate were more mixed than for the security sector. With executive powers to investigate and prosecute serious and sensitive crimes, EULEX's potential to make a meaningful contribution to addressing impunity for violence, war crimes and corruption, all key conflict drivers that have fuelled violence in the region, was widely perceived as high. Nevertheless, civil society organisations involved in the justice sector lament poor delivery overall. A backlog of up to tens of thousands of cases in some courts indicate that EULEX and other actors supporting the Kosovo judicial system have failed in this respect. ${ }^{85}$ Enforcement of decisions was raised as equally problematic, as the 2012 ECA report estimated, only 40per cent of Court rulings in Kosovo were enforced. This has created frustration among the population and civil society organisations involved in transitional justice and criminal prosecution. This was stressed in particular for cases related to elite corruption, which EULEX has been criticised for not pursuing enough in the eyes of local populations and civil society. ${ }^{86}$

EULEX's ambitious mandate combined with its lack of concrete deliverables led to high expectations in Kosovo. At its launch, the mission was widely expected to prosecute senior political figures involved in alleged crime and corruption. On this account, EULEX has disappointed. However, with regard to its contribution to preventing further instability, the mission has made a meaningful contribution in particular in the North, where the risk was highest. It has had a direct impact on security provision through policing, but also an indirect effect on the provision of security through rule of law. To date, EULEX has contributed to preventing further violence in Kosovo. The question now is, whether with waning local support the mission may lose its ability to contribute meaningfully without using disproportionate measures to that end.

\section{Did EULEX Kosovo apply proportional measures?}

With executive powers and a wide range of tools and resources at its disposal, the EULEX mission was perceived as promising at its launch in 2008. A decade on, the political context has changed, its mandate has narrowed and the threat of large-scale violence has decreased. ${ }^{87}$ Even though the mission was downsized to 800 staff in 2017, EULEX's resources

84 Interview 12.

85 European Commission 2016, 37; Interview 10.

86 Saferworld 2011; Interviews 9-14.

87 Interviews 3, 6, 9, 10 and 11; Council of the EU 2016b. 
are still deemed by all civil society respondents interviewed for this project as disproportionately high in view of its results. ${ }^{88}$ EULEX is no longer deemed to deliver effective security provision on the ground proportional to the resources invested in it. When asked, respondents put forward several reasons why the mission might not fulfil its potential. These echoed public perception surveys, which lamented a lack of accountability towards Kosovo's people. Mission staff was seen to be working towards the interests of the EU member states that pay their salaries, which has not created cohesion around the mandate of the mission or indeed the needs of the local population..$^{89}$ The mission's reputation was further tarnished by corruption allegations..$^{90}$ In 2014 EULEX officials stood accused of bribery and inappropriate involvement with Kosovo officials suspected of corruption. These allegations covered by local and international media proved damaging to the credibility of the mission, which is mandated to fight corruption. ${ }^{91}$ This has caused decreasing trust in EULEX from local civil society and populations. ${ }^{92}$ Connected to the issue of trustworthiness is a perceived lack of transparency and adequate scrutiny of EULEX actions, especially concerning its coercive power through the executive mandate. Respondents agree that the mission neither consults nor communicates well enough with the people that are supposed to be its primary beneficiaries. Likewise, its monitoring and evaluation processes are neither perceived as transparent nor participatory. ${ }^{93}$ After a period of regular consultations during its initial deployment, formal dialogues between EULEX and civil society have decreased and informal exchanges are reported as non-existent, in spite of requests therefore. ${ }^{94}$ Respondents see this withdrawal from local level dialogue as a major impediment to the mission fulfilling its potential.

In 2011 Saferworld reported that: "EULEX continues to be criticised for performing below expectations. Surprisingly, this is notwithstanding the fact that people increasingly think that the mission had a positive impact on the performance of key justice and security providers in the country. ${ }^{\prime 95}$ Today the first part of the statement holds true, as popular expectations remain unfulfilled, while the benefits referred to in the second part of the statement seem further away. The majority of civil society respondents perceive EULEX's contemporary contribution as disproportionate, weak or negligible. The discrepancy between strategic ambitions, operational means and actual delivery on the ground is considered so high that civil society organisations consulted for this study no longer see the mission as an added value for Kosovo, whether this is to prevent violence or build peace through the rule of law. This clashes slightly with local perceptions reported by the 2016

88 Council of the EU 2016.

89 Interview 12, 13 and 14.

90 Interview 12, 13 and 14.

91 Borger 2014; Capussela 2015a.

92 Tabak and Xharra 2014; KCSS 2016, 13-14.

93 Interviews 9-14; Saferworld 2011.

94 Palm 2010; Interviews 9-14.

95 Saferworld 2011. 
Kosovo Security Barometer. Although frustrations and distrust towards EULEX have never been greater, a small majority of respondents still favour a continued EULEX presence in Kosovo. ${ }^{96}$ Thus, while this study shows that EULEX is widely perceived as wasteful and inadequate, it also shows continued disagreements regarding the proportionality of the mission's means and whether its overall contribution is meaningful enough to justify its presence. This remains a question of whether the glass is half-full or half-empty, and as the EU tends to do in the Western Balkans, it seems willing to air on the side of caution 'just in case'.

\section{Has EUCAP Nestor/Somalia contributed to preventing further insecurity?}

EUCAP Nestor has been commended for being the first maritime mission to adopt an inclusive regional approach to enhancing maritime security, governance and rule of law in the Horn of Africa. ${ }^{97}$ During its mandate, EUCAP has operated across borders including operations in Djibouti, Somalia, Seychelles and Tanzania. The Horn of Africa faces a number of shared security challenges, as identified in the regional conflict analysis above. Taking a regional approach and establishing cooperative partnerships in the region is therefore critical. Cooperation between the different Horn governments is especially important; as it would be impossible to sustain systematic security provision such as an effective anti-piracy campaign without the support and coordination of regional actors. Regional cooperation opens the door to opportunities beyond combating piracy at sea. It provides space for "capacity building in the area of maritime domain awareness, judicial enforcement, information sharing, asset facility sharing and joint counter-piracy/terrorism exercises". ${ }^{98}$ With its initial regional focus, EUCAP Nestor, thus, supported the EU's regional priorities to foster peace and help provide security throughout the Horn. ${ }^{99}$

Nestor's focus on civilian-based maritime security has had a positive impact in terms of building local capacities throughout the region. However, problems persist. A significant one concerns early capacity-building programmes in the country, where regional security problems such as piracy originate. EUCAP Nestor did not operate in Somalia for the first two years of its mandate, despite the piracy problem stemming from within that country. ${ }^{100}$ As a result: "the mission [did not have] a significant impact on the ability of Somali authorities to improve policing and rule of law" in these first two years. ${ }^{101}$ In part to remedy this issue, the EU refocused and renamed EUCAP Somalia, shifting its mandate to focus on that country from 2016 onwards. Consequently, the mission expanded its Hargeisa field office, established an operations' base in Puntland and increased its pres-

96 KCSS 2016.

97 Tejpar and Zetterlund 2013.

98 Onuoha 2010, 212.

99 Council of the European Union 2011b, 4.

100 Ejdus 2017, 11.

101 Quoted in Ejdus 2017, 11. 
ence at the Mogadishu headquarters. ${ }^{102}$ While this may be considered a 'better late than never' reshuffle, it does illustrate willingness on the part of the EU and EUCAP to adapt the mission to better fulfil its preventive potential. Due to its regional approach and focus on capacity-building, EUCAP NESTOR has contributed to strengthening security provision in the Horn of Africa, and later Somalia's ability to respond to piracy and other maritime security issues. However, EUCAP NESTOR's contributions are less effective than other engagements such as EUNAVFOR and measures that focus more directly on security provision such as increased patrols and higher security for ships. The next question, therefore, is whether EUCAP applied proportional measures of prevention.

\section{Did EUCAP Nestor/Somalia apply proportional measures?}

EUCAP's approach of building capacity through the promotion of local ownership can be seen specifically in the mission's efforts to strengthen maritime capabilities and the rule of law in Puntland, Somaliland and Galmudug. This was pursued via onshore trainings, support for a coastal police force and the training of judges in Puntland. ${ }^{103}$ EUCAP Nestor encouraged the Federal Somali Government and Somali Regional States, including Somaliland, to meet with international partners such as the UN and OBP. One of the meetings between these entities led to the May 2016 opening of the Interim Operations Room for the Somaliland Coast Guard. ${ }^{104}$ This and related initiatives sought to enhance awareness and capacity for maritime management and coordinated security responses. ${ }^{105}$ EUCAP's engagement with authorities in Somaliland is an example of the process and results of local buy-in. EUCAP Nestor and the Republic of Somaliland agreed that the mission would take a 'bottom up' approach aligned with Somaliland's National Maritime Development Plans. ${ }^{106}$ Another practical example of EUCAP Nestor's promotion of local ownership can be seen in its work with the Somaliland Coast Guard to develop a website. ${ }^{107}$ EUCAP facilitated partnership between a Somaliland IT expert and the coast guard's self-educated IT team. Internally, the project was considered a success, especially as it was perceived as a project "by Somalilanders for Somalilanders". ${ }^{108}$ The approach exemplified in that project provides support for the EU to prioritise local ownership and community engagement. By making these principles a priority, EU missions are likely to improve both in terms of their ability to enhance local capacity and the amount of local engagement in and support for the missions, which is essential to their success.

102 EEAS 2016a, 20.

103 Holzer and Jürgenliemk 2012, 9.

104. EEAS 2016a, 20.

105 Ibid.

106 Somaliland Coast Guard 2015.

107 EEAS 2014a.

108 Ibid. 
While EUCAP's mission highlights the importance of a locally owned approach, and while there have been instances of local ownership. Overall, "EUCAP Nestor has struggled to achieve ownership because it implemented ownership as an externally driven, top-down endeavour"; an assessment echoed by internal and external commentators alike. ${ }^{109}$ These issues are further highlighted by the fact that it was not until the refocusing of EUCAP Nestor and during the process of creating a new operational plan for EUCAP Somalia that the Somali government was fully consulted about its needs. Thus, it was only five years into the mission that key government actors were consulted and the Somali maritime context was appropriately reflected and incorporated into the mission mandate. ${ }^{110} \mathrm{EU}$ CAP was further distanced from the local context due to the EU mission's structure, management style and "the tendency to micro-manage the mission from Brussels". ${ }^{111}$ External actors have criticised the bureaucracy that accompanied the operation on the EU side, accusing it of alienating local actors, damaging their trust in the EU and EUCAP, while it "overwhelmed the mission with red tape".112

The EU has increasingly engaged in and funded activities in the Horn of Africa such as EUCAP Nestor with the aim of promoting security, but its efforts have suffered from lack of cohesion and a mismatch between means and ends. Overall, EU policy towards the Horn of Africa prioritises security and stability through an underlying theme of promoting 'African solutions to African problems.'113 This approach is intended to build Africa's capacity to address its own problems, minimising external interventions, and encouraging the emergence of African institutions such as IGAD and the AU. ${ }^{114}$ EU programmes and priorities in the Horn, such as EUCAP, however, frequently fail to adequately take into account the local context and the limited governmental and institutional capacity in the region. ${ }^{115}$ EUCAP Nestor was the first mission of its kind and as such it can serve as a useful learning model for future EU actions. Both in terms of its achievements and challenges EUCAP provides valuable lessons for regional engagements both in the Horn of Africa and elsewhere. ${ }^{116}$

In sum, EUCAP has had significant achievements and challenges. EUCAP's achievements include the political backing the mission fostered in the region, e.g. in the Seychelles and Somaliland, trainings throughout the Horn of Africa and the mission's complementary

109 Ejdus 2017, 10: “The EU designed the mission according to its own needs, interests and resources and then tried to sell it to its local counterparts. As a result, the overall degree of local ownership has been low, while the impact on the local and regional capacity to fight piracy has been either negligible or unsustainable."

110 Ejdus 2018, 36.

111 Ibid., 12.

112 Ibid.

113 Sicurelli and Fabrinni 2011, 52; Kempin and Scheler 2016, 401.

114 Mays, 2003.

115 Gibert 2006, 148.

116 Madsen and Kane-Hartnett 2013. 
nature with other EU activities. EUCAP has provided learning on leadership in maritime security, capacity-building and political cooperation around the Horn of Africa. A primary lesson identified is that while EUCAP aimed to be a locally owned mission with regional reach, it succeeded in achieving this primarily through framework creation rather than realities in the mission and on the ground. One of the central failings of the mission was its initial lack of operations in Somalia, which was a glaring gap, as much of the insecurity in the region stems from there. EUCAP failed to take local needs and contexts sufficiently into account in creating mission priorities, prioritising its own agenda rather than realities on the ground. ${ }^{117}$ In order to improve future missions the EU must ensure that it operates in mission-critical areas, that it creates trainings that are sustainable and supported by local capacity, that it understands the local context and consults local government, civil society and affected groups among local populations. By doing this, the EU could better ensure that its efforts contribute meaningful, proportional prevention of further insecurity.

\section{Concluding Lessons for the Future}

This contribution appraised the EU's approach to security provision in the Western Balkans and the Horn of Africa. It focused on capabilities developed under the Common Security and Defence Policy and whether their application matched EU regional strategies to address security needs on the ground. The purpose of this endeavour was to examine whether the EU's capabilities are sufficient and appropriate to reach its expectations and those of others - in preventing violence and promoting peace in both regions. The conclusion is that EU engagements in the Western Balkans and the Horn of Africa have made meaningful contributions to preventing further insecurity in both regions but with results generally falling short of both internal and external expectations. The EU's regional strategies constitute a relevant response to local challenges and should be sustained and developed further, but with more context-specific and adaptive flexibility on the ground. To implement these regional strategies to the levels of expectation, the EU must continue its efforts to develop coherent, integrated CSDP packages supporting its overall strategic ambitions and responding directly to the complex security challenges at hand. To this end, it is essential that EU actors and agencies work well together to identify context-specific priorities. Likewise, the EU must work more closely and consistently with international, regional and particularly local actors, including them through continuous consultation and cooperation at all stages from strategy development, fact-finding and planning phases to the launch, implementation, revision, transition and withdrawal of CSDP missions.

This study took a closer look at two such missions. EULEX Kosovo and EUCAP Nestor/ Somalia both provide lessons for future missions to be undertaken by the EU, or indeed other organisations and entities that plan similar initiatives. The most important lessons

117 Ejdus 2018, 39-40. 
from both case studies relate to the importance of: (1) clear and focused mission mandates with concrete benchmarks and verifiable indicators of success that respond to the most important needs on the ground; (2) clarity, consistency and predictability in political support from Member States and institutions staffing, equipping and sustaining the mission throughout its implementation; and (3) sufficient structures for recruiting and retaining appropriate human resources and proper procurement for such deployments. Further lessons identified stress the significance of (4) fostering deeper cooperation with and between countries in host regions, and (5) including local actors in the process of strengthening governments, governance, institutions, rule of law and provision of security. This is crucial to ensure that the EU does not set internal goals that prioritise shortterm security at the cost of the external need for long-term development since both are key to preventing further insecurity and building a sustainable peace. 


\section{References}

African Research Bulletin. 2008. Djibouti-Eritrea: Fighting on Border. 45 (6): 1775817559.

Al Jazeera. 2017. “Somalia soldiers end deadly al-Shabaab restaurant siege." Accessed July 22, 2017. http://www.aljazeera.com/news/2017/06/somalia-soldiers-deadly-alshabab-restaurant-siege-170615063902798.html.

Balkan Investigative Reporting Network (BIRN). 2016. Balkan Jihadists: Radicalization and Recruitment of Fighters in Syria and Iraq. March. Accessed July 20, 2017. http://www.balkaninsight.com/en/file/show/Balkan-Jihadists.pdf.

Baniela, Santiago Iglesias and Rios, Juan Vinagre. 2012. "Piracy in Somalia: A Challenge to the International Community." Journal of Navigation 65 (4): 693-710.

Bereketeab, Redie. 2011. "Rethinking State-Building in the Horn of Africa: Challenges of Striking a Balance between Traditional and Modern Institutions." African Studies 70 (3): 376-392.

Borger, Julian. 2014. "EU's biggest foreign mission in turmoil over corruption row." The Guardian. November 5, 2014. Accessed July 17, 2017. https://www.theguardian. com/world/2014/nov/05/eu-facing-questions-dismissal-prosecutor-allegedcorruption.

Boštjančič Pulko, Ivana and Nina Pejič. 2016. "Drawing Lessons Learnt on Operational Capabilities of EU's CSDP Missions in Kosovo and Bosnia and Herzegovina." European Perspectives - Journal on European Perspectives of the Western Balkans 8 (2): 116 - 136.

Bueger, Christian. 2013. "In search for a mission? The EU's regional training mission EUCAP Nestor." Accessed August 31, 2017. http://piracy-studies.org/in-search-for-amission-the-eus-regional-training-mission-eucap-nestor/.

Buzan, Barry and Ole Wæver. 2003. Regions and Powers: The structure of international security. Cambridge: Cambridge University Press.

van der Borgh, Chris. 2016. "EU peacebuilding capabilities in Kosovo after 2008: an analysis of EULEX and the EU-facilitated Belgrade-Pristina Dialogues". Centre for Conflict Studies: Utrecht University.

Capussela, Andrea Lorenzo. 2015. State-Building in Kosovo. Democracy, Corruption and the EU in the Balkans. London, New York: I. B. Tauris. 
Capussela Andrea Lorenzo. 2015a. "EULEX report exposes EU failure in Kosovo." EU Observer. April 16. Accessed July 17, 2017. https://euobserver.com/opinion/128343.

Čarapić, Jovana. 2014. "Handgun Ownership and Armed Violence in the Western Balkans.” Small Arms Survey. September. Accessed August 3, 2017. http://www. smallarmssurvey.org/fileadmin/docs/G-Issue-briefs/SAS-AV-IB4-Western-Balkans.pdf.

Council of the European Union. 2003. European Security Strategy: a secure Europe in a better world. Brussels, 12 December.

Council of the European Union. 2016. Press release 327/16, June 14. http://www. consilium.europa.eu/en/press/press-releases/2016/06/14-eulex-kosovo-budget/.

Council of the European Union. 2008. Council Joint Action 2008/124/CFSP of 4 February 2008 on the European Union Rule of Law Mission in Kosovo, EULEX Kosovo. Accessed April 4, 2017. http://www.eulex-kosovo.eu/eul/repository/docs/ WEJointActionEULEX_EN.pdf.

Council of the European Union. 2011a. Council conclusions on the Horn of Africa: 3124th Foreign Affairs Council meeting Brussels, 14 November 2011. Accessed July 7, 2017.

http://www.consilium.europa.eu/uedocs/cms_data/docs/pressdata/EN/ foraff/126052.pdf.

Council of the European Union. 2011b. Outcomes of Proceedings, 16858/11, 14 November. Accessed July 7, 2017. http://register.consilium.europa.eu/doc/ srv?l=EN\&f=ST\%2016858\%202011\%20INIT.

Council of the European Union. 2012. Council Decision 2012/389/CFSP. Official Journal of the European Union.July16. Accessed July 7, 2017. http://www.europarl. europa.eu/meetdocs/2009_2014/documents/sede/dv/sede121112cd389_/ sede121112cd389_en.pdf.

Council of the European Union. 2014. Regulation (EU) no 230/2014 of the European Parliament and of the Council, 11 March 2014 establishing an instrument contributing to stability and peace. Official Journal of the European Union. L77. 15 March. pp. Art. 3-5.

Council of the European Union. 2018. "EUCAP Somalia: mission extended, budget agreed.” December 10. Accessed 28 March, 2019. https://www.consilium.europa. $\mathrm{eu} / \mathrm{en} / \mathrm{press} /$ press-releases/2018/12/10/eucap-somalia-mission-extended-budgetagreed/. 
DW. 2017. "Al-Shabab attacks Kenya military base, dozens killed." January 28. Accessed July 22. http://www.dw.com/en/al-shabab-attacks-kenya-military-basedozens-killed/a-37311441.

Ejdus, Filip. 2017. 'Here is your mission, now own it!' The rhetoric and practice of local ownership in EU interventions.” European Security 26 (4): 1-24.

Ejdus, Filip 2018. "Local ownership as international governmentality: Evidence from the EU mission in the Horn of Africa." Contemporary Security Policy 39 (1): 28-50.

Elek, Bojan, Muk, Stevo and Milena Milosevic. 2016. Back to basics: reaffirming the rule of law in the Western Balkans. Podgorica: Institute Alternativa.

Elmi, Afyare, Ladan Affi, Andy Knight, and Said Mohamed. 2015. "Piracy in the Horn of Africa Waters: Definitions, History, and Modern Causes." African Security 8 (3): $147-165$.

EU Council Secretariat. 2005. EU Council Secretariat Factsheet - EU police advisory team (EUPAT) in the former Yugoslav Republic of Macedonia. December. Accessed August 25, 2017. http://www.eeas.europa.eu/archives/csdp/missions-andoperations/eupat/pdf/01122005_factsheet_eupat_en.pdf.

EUCAP Somalia. 2017. "European Union Capacity Building Mission in Somalia. EUCAP Somalia." Accessed August 3, 2017. http://www.eucap-som.eu/fact-sheet.

EULEX. 2019. "EULEX - European Rule of Law Mission Kosovo." Accessed August 8, 2019. https://www.eulex-kosovo.eu/.

EULEX. no date. "EULEX Accountability." Accessed July 13, 2017. http://www.eulexkosovo.eu/?page=2,23.

EUNAVFOR Somalia. no date. "Mission." Accessed April 11 2019. https://eunavfor. eu/deployed-units/surface-vessels/\#news-tabs.

EUPOL Proxima. 2003. "European Union Police Mission PROXIMA - Fact Sheet, December 2003." Accessed August 25, 2017. http://fedtrust.co.uk/wp-content/ uploads/2014/12/Crisis_Management_Policy_Brief.pdf.

European Commission. 2016. The former Yugoslav Republic of Macedonia 2016 Report, November. Accessed July 25, 2017. https://ec.europa.eu/neighbourhoodenlargement/sites/near/files/pdf/key_documents/2016/20161109_report_the_ former_yugoslav_republic_of_macedonia.pdf. 
European Commission. 2016a. Actions in support of peacebuilding and conflict prevention in the Horn of Africa within the EU Emergency Trust Fund. Brussels: EU Commission.

European Commission. 2017. 2017 Economic Reform Programmes of Albania, the former Yugoslav Republic of Macedonia, Montenegro, Serbia, Turkey, Bosnia and Herzegovina and Kosovo. June. Accessed July 21, 2017. https://ec.europa.eu/info/ sites/info/files/ip055_en.pdf,

European Commission. 2017a. ACP - The Cotonou Agreement. https://ec.europa.eu/ europeaid/regions/african-caribbean-and-pacific-acp-region/cotonou-agreement_en.

European Court of Auditors (ECA). 2012. European Union Assistance to Kosovo Related to the Rule of Law, Special Report $n .^{\circ} 18$, Luxembourg: European Court of Auditors. http://www.eca.europa.eu/Lists/ECADocuments/SR12_18/SR12_18_ EN.PDF

European Parliament. 1993. Presidency conclusions of the Copenhagen European Council on the 21st and 21nd June 1993. Accessed August 7, 2017. http://www. europarl.europa.eu/enlargement/ec/cop_en.htm.

European Parliament. 2015. The Western Balkans and the EU Enlargement: Lessons learned, ways forward and prospects ahead. Accessed August 7, 2017 http://www.europarl.europa.eu/RegData/etudes/IDAN/2015/534999/EXPO_ IDA\%282015\%29534999_EN.pdf.

European Parliament. 2016. The Berlin Process and Regional Cooperation in the Western Balkans: How to make agreements more effective and efficient? Accessed August 7, 2017. http://www.europarl.europa.eu/RegData/etudes/BRIE/2016/586602/ EPRS_BRI(2016)586602_EN.pdf.

European External Action (EEAS). 2012. Common Security and Defence PolicyEuropean Union Mission in Bosnia And Herzegovina (EUPM), June 2012. Accessed August 25, 2017 https://eeas.europa.eu/archives/csdp/missions-and-operations/ eupm-bih/pdf/25062012_factsheet_eupm-bih_en.pdf.

European External Action Service (EEAS). 2013. EUCAP Nestor Welcomes Successful Completion of Senior Maritime Security Course on board EU Naval Force Flagship, 26 August. Accessed July 9, 2017. https://www.eucap-nestor.eu/en/press_office/ news $/ 367 /$ ?year=2013\&month $=12$.

European External Action Service (EEAS). 2014a. EUCAP Nestor assists Somaliland Coastguard (SLCG) in boosting external communication, 9 
December. Accessed July 7, 2017. https://www.eucap-nestor.eu/en/press_office/ news $/ 945 /$ ? year $=2014 \&$ month $=12$.

European External Action Service (EEAS). 2014b. Regional Maritime Security Capacity Building Mission in the Horn of Africa and the Western Indian Ocean (EUCAP Nestor). November. Accessed July 7, 2017 http://www.eeas.europa.eu/ archives/docs/csdp/missions-and-operations/eucap-nestor/documents/factsheet eucap_nestor_en.pdf.

European External Action (EEAS). 2014a. EU Common Security and Defence Policy - European Union Aviation Security Mission (EUAVSEC) in South Sudan. February 2014. Accessed August 25, 2017. http://www.eeas.europa.eu/archives/csdp/missionsand-operations/euavsec-south-sudan/pdf/factsheet_euavsec_south-sudan_en.pdf

European External Action (EEAS). 2014b. Common Security and Defence Policy - EULEX Kosovo - EU Rule of Law Mission in Kosovo, October 2014. Accessed on August 25, 2017. http://eeas.europa.eu/archives/docs/csdp/missions-andoperations/eulex-kosovo/pdf/factsheet_eulex_kosovo_en.pdf.

European External Action Service (EEAS). 2015. PR21_2015: Maritime security workshop held in Mogadishu. 27 May. Accessed July 9, 2017. https://www.eucapnestor.eu/en/press_office/news/1282/?year=2015\&month=12.

European External Action (EEAS). 2015a. European Union Common Security and Defence Policy - EU military operation in Bosnia and Herzegovina (Operation EUFOR Althea). January 2015. Accessed August 25, 2017. http://eeas.europa.eu/ archives/csdp/missions-and-operations/althea-bih/pdf/factsheet_eufor_althea_ en.pdf.

European External Action Service (EEAS). 2016. Missions and Operations Annual Report 2016. Brussels: European Union External Action Service.

European External Action Service (EEAS). 2016a. Common Security and Defence Policy of the European Union: Missions and Operations Annual Report. Brussels:

European Union External Action. Accessed July 7, 2017. https://eeas.europa.eu/sites/ eeas/files/e_csdp_annual_report1.pdf.

European External Action Service (EEAS). 2016b. EUCAP Nestor and EU NAVFOR Atalanta seek further synergies for enhancing maritime capacity building in Somalia. 23 June. Accessed July 9, 2017. https://www.eucap-nestor.eu/en/press_office/ news $/ 1367 /$ ?year $=2016 \&$ month $=12$.

European External Action Service (EEAS). 2016c. EUCAP Nestor's Maritime Advisor embarks on EU NAVFOR's Operation Atalanta flagship. 18 August. 
Accessed July 9, 2017. https://www.eucap-nestor.eu/en/press_office/ news $/ 1391 /$ ?year $=2016 \&$ month $=12$.

European External Action Service (EEAS). 2016d. EU Maritime Security Capacity Building Mission in Somalia (EUCAP Nestor). November. Accessed on 7 July, 2017. https://www.eucap-nestor.eu/data/file/1427/EUCN_Factsheet_November_2016. qF1oOOwtvM.pdf.

European External Action (EEAS). 2017a. Common European Defence Policy European Union Training Mission - Somalia. August, 2017. Accessed August 25, 2017, https://www.eutm-somalia.eu/about-us/.

European External Action (EEAS). 2017b. Common Security and Defence Policy - EU Capacity Building Mission in Somalia (EUCAP Somalia). February 2017. Accessed on August 25, 2017. https://www.eucap-som.eu/fact-sheet/.

European External Action Service (EEAS). no date. "Common Security and Defence Policy: EUCAP Nestor." Accessed July 9, 2017.

http://www.europarl.europa.eu/meetdocs/2009_2014/documents/sede/dv/ sede012313factsheeteucapnestor_/sede012313factsheeteucapnestor_en.pdf.

European Union. 1999. The Stabilisation and Association Process (SAP). Accessed August 7, 2017. http://eur-lex.europa.eu/legal-content/EN/ TXT/?uri=URISERV\%3Ar18003.

Gibert, Marie 2006. "The European Union in the IGAD-Subregion: Insights from Sudan \& Somalia." Review of African Political Economy 33 (107): 142-150.

Government of Montenegro. 2016. Regional Serious and Organised Crime Threat Assessment. Accessed July 21, 2017. http://www.mvr.gov.mk/Upload/Editor_Upload/ analizi-statistiki/Socta\%20izvestaj\%202016\%20ENG.pdf.

Greiçevci, Labinot. 2011. "EU Actorness in International Affairs: The Case of EULEX Mission in Kosovo." Perspectives on European Politics and Society 12 (3): 283-303.

Grilj, Blaž, and Rok Zupančič 2016. "Assessing the Planning and Implementation of the EU Rule of Law Missions: Case Study of EULEX Kosovo." European Perspectives - Journal on European perspectives of the Western Balkans. 8.2 (15): 62-85.

Holzer, Georg-Sebastian, and Hubertus Jürgenliemk. 2012. "The Somali crisis and the EU: Moving onshore and committing to Somalia." GGI Analysis Paper 5/2012. Brussels: Global Governance Institute. Accessed July 7, 2017. http:// 
kops.unikonstanz.de/bitstream/handle/123456789/25612/Holzer_256122. pdf? sequence $=2$ \&isAllowed $=y$.

IECEU. 2016. “IECEU roundtable of experts: Balkans.” Accessed 15 July, 2017. http:// www.ieceu-project.com/?p=536.

International Maritime Organization (IMO). no date. "Frequently Asked Questions." http://www.imo.org/en/About/Pages/FAQs.aspx. Accessed July 222017.

Jacque, Jean-Paul. 2015. "Review of the EULEX Kosovo mission's implementation of the mandate with a particular focus on the handling of recent allegations." Accessed December 11, 2016. http://eeas.europa.eu/statements- eeas/docs/150331_jacquereport_en.pdf.

KCSS. 2016. "Kosovo Security Barometer. Sixth Edition.” http://www.qkss.org/ repository/docs/KSB-Sixth-Edition_327922.pdf.

Kempin, Ronja, and Ronja Scheler. 2016. "The EU in the Sahel and the Horn of Africa." In The EU, strategy and security policy: regional and strategic challenges, edited by Laura Chappell, Jocelyn Mawdsley, and Petar Petrov. London: Routledge, 35-50.

Krešić, Ana, Jakov Milatović, and Peter Sanfey. 2017. "Firm performance and obstacles to doing business in the Western Balkans." European Bank for Reconstruction and Development. January. Accessed July 21, 2017. http://www.ebrd. com/publications/working-papers/firm-performance.

Kursani, Shpend. 2015. Police Cooperation between Kosovo and Serbia. Belgrade and Prishtina: BCSP and KCSS. Accessed 13 July, 2017.

http://www.bezbednost.org/upload/document/police_cooperation_ks_eng_v3.pdf.

Kursani, Shpend. 2013. A Comprehensive Analysis of EULEX. What Next? Pristina: KIPRED.

Ladzik, Jeanette. 2009. "EU Military and Civilian Crisis Management Operations: the first six years.” The Federal Trust and Global Policy Institute. April 2009. Accessed August 25, 2017. http://fedtrust.co.uk/wp-content/uploads/2014/12/Crisis_ Management_Policy_Brief.pdf.

Lyons, Terrence. 2009. "The Ethiopia-Eritrea Conflict and the Search for Peace in the Horn of Africa." Review of African Political Economy 36 (120): 167-180. 
Madsen, Jens Vestergaard, and Liza Kane-Hartnett. 2013. Towards a Regional Solution to Somali Piracy: Challenges and Opportunities. Broomfield, CO: One Earth Future Foundation and Oceans.

Marty, Dick 2011. Inhuman treatment of people and illicit trafficking in human organs in Kosovo. Council of Europe Parliamentary Assembly. Committee on Legal Affairs and Human Rights. Doc. 12462. 7 January. Accessed 24 April 2017. http://semantic-pace. net/tools/pdf.aspx?doc=aHR0cDovL2Fzc2VtYmx5LmNv-ZS5pbnQvbncveG1sL1hSZ WYvWDJILURXLWV4dHIUYXNwP2ZpbGVpZD0xMjYwOCZsYW5nPUVO\&xsl=aH R0cDovL3NlbWFudGljcGFjZS5uZXQvWHNsdC9QZGYvWFJIZi1XRC1BVC1YTUwyUERGLnhzbA==\&xsltparams=ZmlsZWlkPTEyNjA4.

Maxted, Julia and Abebe Zegeye. 2002. "Human Stability and Conflict in the Horn of Africa." African Security Review 11 (1): 54-59.

Murphy, Sean D. 2016. “The Eritrean-Ethiopian War (1998-2000).” In International Law and the Use of Force: A Case-Based Approach, edited by Olivier Corten and Tom Ruys. GWU Law School Public Law Research Paper No. 2016-52. Accessed July 23, 2017. http://scholarship.law.gwu.edu/cgi/viewcontent.cgi?article=2492\&context=fac ulty_publications.

Oceans Beyond Piracy (OBP). no date. “About.” Accessed July 19, 2017. http:// oceansbeyondpiracy.org/about.

Onuoha, Freedom C. 2010. "Piracy and Maritime Security off the Horn of Africa: Connections, Causes, and Concerns." African Security 3 (4): 191-215.

Palm, Malin 2010. Accountability and Effectiveness of CSDP Missions: The Role of Civil Society (The cases of EULEX Kosovo and EUPOL COPPS). EPLO. http://eplo. org/wp-content/uploads/2017/04/EPLO_CSDP_WG_Study_Accountability_and_ Effectiveness_of_CSDP_Missions.pdf.

Rodt, Annemarie Peen. 2016. "European 'Stabilisation through Association': Five Lessons for Future Stability." In Regional Stability and Peacebuilding: Initiating Reconciliation between Afghanistan, Pakistan and beyond, edited by David Vestenskov. Royal Danish Defence College, 59-76. Accessed July 30, 2019. https:// pure.fak.dk/files/6027145/Regional_Stability_Net.pdf.

Rodt, Annemarie Peen. 2017. "Effectiveness in operational conflict prevention: how should we measure it in EU missions and operations". In Seminar Publication on Contemporary Peace Operations - From theory to practice, edited by Elisa Norvanto and Hanne Dumur-Laanila. Finnish Defence Forces International Centre: FINCENT Publication Series 2/2017, 79-86. Accessed October 6, 2017. http:// 
www.doria.fi/bitstream/handle/10024/143913/EAPTC_Seminar\%20Publication. pdf? sequence $=2$ \&isAllowed $=y$.

Rodt, Annemarie Peen et al. 2017. Report on EU Conflict Prevention and Peacebuilding in the Horn of Africa and Western Balkans. EU-CIVCAP Deliverable 5.1, 1-98. Accessed December 20, 2017. https://eucivcap.files.wordpress. com/2017/10/eu-civcap_deliverable_5-1.pdf.

Saferworld. 2011. "Public perceptions of safety and security in Kosovo: Time to Act." http://www.saferworld.org.uk/downloads/pubdocs/Kosovo_tracker_survey_2011_ English_reduced.pdf

Sheremeti, Furtuna. 2017. "Understanding Kosovo's 'Special Court. Kosovo 2.0.” March 6. Accessed April 20, 2017. http://kosovotwopointzero.com/en/ understanding-kosovos-special-court.

Sicurelli, Daniela, and Sergio Fabbrini. 2014. "An institutional approach to foreign policy-making: the EU, the USA and crisis management in Africa." Journal of Transatlantic Studies 12 (1): 41-61.

Somaliland Coast Guard. 2015. "Joint Action Plan Somaliland 2014-2016". September 8. Accessed August 31, 2017. http://www.somalilandcoastguard.com/assets/2015-0912--sl-cpc---eucn---unodc-tripartite-joint-action-plan-v5-1.pdf.

Tabak, Nate and Jetta Xharra. 2014. "Scandal and Suspicion at the EU's Kosovo Mission.” Balkan Investigative Reporting Network (BRIN). November 7. Accessed April 20, 2017. http://www.balkaninsight.com/en/article/scandal-and-suspicion-atthe-eu-s-kosovo-mission-1.

Takele, Alexander. 2017. "Al-Shabaab's Resurgence in the Horn of Africa: Factors Contributing to the Group's Persistence." Ifriqiya 3 (1). Accessed July 17, 2017.

http://dayan.org/content/al-shabaab\%E2\%80\%99s-resurgence-horn-africa-factorscontributing-group $\% \mathrm{E} 2 \% 80 \% 99$ s-persistence.

Tardy, Thierry, ed. 2017. Recasting EU Civilian Crisis Management. Paris: EU Institute for Security Studies.

Tejpar, Johan and Kristina Zetterlund. 2013. "EUCAP Nestor: Trying to Steer Out of the Doldrums." Stockholm: FOI. Accessed July 8, 2017. http://hlo-daktari.de/wpcontent/uploads/2013/12/EUCAP-NESTOR-Tejpar-and-Zetterlund-FOI-R-3721.pdf.

United Nations Assistance Mission in Somalia (UNSOM). no date. "Mandate." Accessed July 21, 2017. https://unsom.unmissions.org/mandate. 
United Nations Development Programme (UNDP). no date. "Frequently Asked Questions.” Accessed July 23, 2017. http://www.undp.org/content/undp/en/home/ operations/about_us/frequently_askedques tions.html.

Weldesellassie, K. Isaac. 2011. "IGAD as an International Organization, Its Institutional Development and Shortcomings." Journal of African Law 55 (1): 1-29.

Welski, Derek M. 2014. Hybrid Court System in Kosovo: Has EULEX proven to be the device to strengthen the independence and effectiveness of Judiciary. Pristina: Group for Legal and Political Studies.

Zupančič, Rok et al. 2016. The Balkans Conclusion's Report. IECEU project, deliverable 5.2. Accessed April 20, 2017. http://www.ieceu-project.com/?page_ id $=2988$. 